\title{
Effectiveness of Technology Based Online Teaching Pedagogy During Covid-19
}

\author{
Cyndrella V S \\ Assistant Professor, Pavanatma College Murickassery, Kerala, India
}

\begin{abstract}
Article Info

Volume 8, Issue 6

Page Number : 76-91

Publication Issue

November-December-2021

Article History

Accepted : 01 Nov 2021

Published : 10 Nov 2021

This study aims to find out the effectiveness of technology based online teaching paradigm. The recent unprecedented outbreak of coronavirus did really narrate the harsh realities of life that human beings should adapt to. One among them was the need to adapt to techno-savvy accomplishments. With the outbreak of this epidemic, there has been significant surge in the usage of all digital platforms like language apps, virtual tutorials, video conferencing tools and online learning software's. All schools are shut and nearly 1.2 billion children are forced to adapt to this harsh reality of online digital platform. Some believe that this online platform would develop a new hybrid model of education with some significant technological benefits, while some others pose the challenges involved in going digitalized. However the students are the ultimate victims who are going to face the consequences of online teaching pedagogy, be it favorable or unfavorable. Thus this study aims to find out the acceptance and effectiveness of online teaching from the part of students. The reflections and viewpoints of students are analyzed to find out the level of confidence and acceptance with regard to large scale online teaching. The test results prove that an established and completed system of IT infrastructure and internet connectivity for all students could pave a way for continuous online learning in the coming years.
\end{abstract}

Keywords : IT Infrastructure, Online Learning, Covid-19

\section{INTRODUCTION}

The emergence of the unprecedented epidemic has impacted the economy's educational sector to a large extent. The impact of Covid-19 has forced government to take many restrictions in the fields of travel, education, industries etc. In order to stop the spread of virus among the adult, youth, children government has taken the steps for closure of universities, schools, gyms, hotels, etc. As per the records nearly 150 countries have closed their schools and suspended all the activities like workshops, seminars, conferences, sports and other activities. Universities and schools have moved on

Copyright: () the author(s), publisher and licensee Technoscience Academy. This is an open-access article distributed under the terms of the Creative Commons Attribution Non-Commercial License, which permits unrestricted non-commercial use, distribution, and reproduction in any medium, provided the original work is properly cited 
to complete digitalized learning platforms. And because of this there is significant surge in the usage of all digital platforms like language apps, virtual tutorials, video conferencing tools and online learning software's. Responding to this shift from traditional face to face education to online, many online platforms have started providing free access to their services. Recent innovations like Byjus app Tencent, Lark, Alibabas distance learning solution has become highly valued edtech companies.

Private schools have adapted to their own applications like NLP app and other software applications. Kendra Vidyalaya and other central schools have adapted Swayam Prabha Portal which had DTH and online Lectures. Government schools have adopted classes through Victors Channel. Colleges and Universities deploy Zoom App, Google Classroom, Webex Meet etc. Google classroom is free web service which could be accessed by colleges and schools. Many channels like Discovery Education, TED EX have started providing lessons in school subjects, conduct of quizzes and challenges. It is true that Corona Virus had introduced a changing imperative trend of $\mathrm{E}$ learning Platform. And this has resulted in the largest online movement in the history with approximately $81 \%$ of the students attending classes through digital platforms. Within this short period of time even government has taken many necessary steps for ensuring education of students through online mode. Millions of students and their teachers have started to share their screen via internet sitting at home and students accessing the same. However it is doubtful as to the effectiveness and acceptance level by students regarding these online platforms.

The need of complete adaptability to techno savvy advancements is still a distant dream for many underprivileged and marginalized sections of the society. It is still a harsh reality for many poor students.
Many students do not have reliable access to internet facility. Many of the villages and hilly areas are prone to connectivity and network issues. The inaccessibility to good network coverage is a major hindrance for online education to those students in villages, remote and hilly areas. Those from underprivileged background do not have adequate technology like computer or android mobile phones to hold on. These students really struggle to participate in online learning platforms. Even if government is taking adequate steps to provide equipment's for E- learning, it's not reaching to the hands who are in really need of it. Some of the private schools are gaining popularity because of this digital platform. Many of the government schools in rural areas are not having any access to these technologies. Students from rural background are not being able to make use of this opportunity. As per the National Sample Survey, only less than $15 \%$ of rural Indian households have Internet (as opposed to $42 \%$ urban Indian households). A mere $13 \%$ of people surveyed (aged above five) in rural areas and just $8.5 \%$ of females know to use the Internet. The poorest households in India cannot afford to have a smartphone or a computer.

Students who use the digital platforms are also being forced to spend most of their time in front of the screen which can also distract them to other internet sites. Inside the classroom every teacher had a unique style of teaching and special care to each student which cannot be imparted in this platform, so children are becoming careless regarding their studies. Students in colleges are also not serious with their studies as they are not forced to make them sit and attend the classes as done inside the classroom.

Even if this situation is causing a digital divide during this pandemic and lockdowns, there is still a ray of hope for the students as many initiatives are 
being taken from the part of Government, private sectors etc. There is increased interest and high competence from all policy makers for making education a sustainable one. Thus we can hope that this will counterbalance the negative trends reported by students. And this study is focusing to identify the effectiveness of online teaching from the perspective of students and to test their attitude towards this new medium of teaching.

\section{Statement of the problem}

Till March 2020 the education system in India was most relied upon conventional method and tools of teaching. But with the spread of global pandemic we were forced to jump into online modes to carry out the learning process. India was forced to announce complete lockdown from $25^{\text {th }}$ march onwards, this strategic decision by the government affected all sectors of the nation. Due to the decision universities and schools were compelled to close for an uncertain period and exams were postponed. We can't take a breath on teachinglearning process, or even stop teaching learning process for a few period of time. Hence in a short period of time teachers started to teach in front of screen and their students have to complete their courses through internet. The study is focusing to identify the effectiveness of online teaching from the perspective of students and to test their attitude towards this new medium of teaching.

\section{Objectives}

- To identify most preferred platform by students for online classes

- To test students attitude towards online teaching paradigm

- To find difficulties faced by students in following online classes
- $\quad$ To test level of confidence of students for facing future challenges and examinations after attending classes through digital media.

\section{METHODOLOGY OF THE STUDY}

The Survey on effectiveness of online teaching pedagogy was conducted during the time of prime move taken by government to conduct online classes for all educational institutions. The survey was conducted via email campaign. Study was addressed by nearly 1200 respondents from various colleges across Kerala. Majority of the questions was closed ended. These questions provided an opportunity for the students to report on the most challenges faced by them in the midst of current crisis. These questions also allowed them to identify the future impacts that may affect our education system. Both primary and secondary data was used for the study.

Sample design was snowball sampling. Here random respondents itself recommended further samples to be collected. The respondents belonged to the age group of 16-25 years

\section{SIGNIFICANCE OF THE STUDY}

Technological advancements, improved standard of living, high level of education, have paved a way for everyone to give importance to education. However, as soon as the Covid-19 crisis broke out almost all sectors of educational institutions suspended their academic activities and they were forced to follow online procedures. Even many of the institutions cancelled their examinations. Many platforms were emerged for the purpose of handling online classes. Universities adopted Zoom, Webex Meet, Google Classroom, whereas support was initiated by MHRD, NCERT by providing courses like MOOC, e-PG Pathshala (e-content), SWAYAM (online courses for teachers), and NEAT (enhancing 
employability).Courses and materials are available in National Project on Technology Enhanced Learning (NPTEL), National Knowledge Network, (NKN), and National Academic Depository (NAD).

It is strongly advocated that educational institutions are utilizing full power technology. It is also believed that this situation is going to persist for longer duration. However there are some challenges faced by students. This study aims to find out the difficulties faced by students, effectiveness of online education and their confidence to challenge the future with their outcome with its suggestive measures.

\section{SCOPE OF THE STUDY}

The scope of the study is to find out the effectiveness of Online teaching pedagogy during Covid-19. It is limited by the respondents of college students from Kerala. This study was conducted during the pandemic of Covid-19 and it also relevant further as it is also analyzed that the same trend will continue for further years from now.

\section{TOOLS FOR ANALYSIS}

A research tool plays a major role in any worthwhile research as it is the sole factor in determining the sound data and in arriving at true conclusions about the problem of the study which also ultimately helps in providing remedial measures to the problems concerned. Here the main tool used was the questionnaire for collecting the data's. The collected data were analyzed through various statistical techniques like ratios, and percentage. Necessary charts, diagrams, and tables are prepared to simplify the complex data into an understandable easy manner.

\section{REVIEW OF LITERATURE}

The study "Education and the COVID-19 pandemic" has suggested guidance to teachers, institutional heads, and officials on addressing the crisis. What preparations should institutions make in the short time available and how do they address students' needs by level and field of study? Reassuring students and parents is a vital element of institutional response. In ramping up capacity to teach remotely, schools and colleges should take advantage of asynchronous learning, which works best in digital formats. As well as the normal classroom subjects, teaching should include varied assignments and work that puts COVID-19 in a global and historical context. They assure that The COVID-19 pandemic is a huge challenge to education systems (Daniel, 2020).

The study was conducted to survey prospective international students, which provides services, analytics, and insight to the global higher education sector globally, 11,000 respondents When asked whether the virus had impacted their plans to study abroad, $46 \%$ said it had, 29\% said it did not and 25\% said they did not know and another significant finding is that $58 \%$ of prospective international students expressed some interest in studying their degree online due to coronavirus restrictions, while only $42 \%$ stated that they had no interest in studying online. It was concluded that the great challenge is how to move from traditional education to e-learning and how to overcome the problem of practical courses and training (Henebery, 2020)

The study was focused on surveying the impact of Covid-19 in Africa's higher education and research sector and surveyed 501 individuals affiliated with higher education and research institutions across the continent. Only $17 \%$ of West African respondents reported being at institutions with elearning options, compared to $43 \%$ of East African respondents and $41 \%$ of respondents in Southern Africa, which suggests that while there are many similar issues plaguing the continent, the regional specific nuances are key in considering how to 
resolve these issues. The study also found that more women reported their institutions providing elearning ( $46 \%$ compared to $34 \%$ of men). Respondents aged between 40-49 years old also reported higher rates of access to e-learning in comparison to other age groups. From this study it was clear that majority of students does not support e-learning options. (KARI MUGO, 2020)

The study was made to analyze the Impact of COVID-19 on the Education Sector in Nepal it was found that, the existing system of education and the uneven distribution of its resources have often been blamed for the widening gaps between the haves and have-nots; in the advent of COVID-19, the digital divide and the uneven access to e-learning and e-resources will increase the gaps and external assessments, their postponement has a direct impact on students as the educational and occupational future of students depends on their outcomes. It is estimated that the COVID-19 impact on the Nepalese education might resemble the impact of Ebola epidemic (on education) in Africa. And concluded that it is evident that the COVID-19 pandemic has created some sort of educational anarchy with the government having no firm grip of the educational system. If proper actions are not taken on time, the whole education system will be stagnant or even collapse(Dawadi, 2020)

"Exploring the critical challenges and factors influencing the E-learning system usage during COVID-19 pandemic" After this review, they noted that these challenges could be classified into four categories namely (1) technological challenges, (2) individual challenges, (3) cultural challenges and (4) course challenges. They also found that these challenges are very different from one country to another country, due to different culture, context and readiness. For example, lack of ICT knowledge, poor network infrastructure and weakness of content development were the main challenges of e-learning system adoption in developing countries (Aung and Khaing 2015).

Another study revealed that system characteristics, internet experience and computer self-efficacy were the main issues that impede the successful adoption of e-learning system in Pakistan (Kanwal and Rehman 2017). A similar study conducted in Kenya identified three main challenges of e-learning are inadequate ICT infrastructure, lack of technical skills and financial constraints (Tarus et al. 2015). A study by Kisanga and Ireson (Mulhanga and Lima 2017) identified that poor interface design; inadequate technical support and lack of IT skills are the primary barriers that hinder the successful implementation of existing e-learning projects. Mulhanga and Lima (Kenan et al. 2013) claimed that cultural, political, and economical constraints are the main reasons to fail the e-learning initiatives in Libya. In the same way, Kenan et al. (Chen and Tseng 2012) classified the challenges that affect the actual use of e-learning into four categories: management challenges, technological challenges, implementation challenges and cultural challenges. Despite these efforts, none of these studies have investigated the actual challenges that face users during the use of e-learning system.

A study conducted by Al-Araibi et al. (2019), which puts the technological issues as the main criteria for the success of e-learning system, indicated that $45 \%$ of e-learning projects in developing countries are total failures, $40 \%$ are partial failures, while only $15 \%$ are successful. Therefore, based on these findings, along with other studies, many researchers in the field of IS/IT have conducted researches in order to look into the challenges to the successful implementation of e-learning system initiatives (AlAraibi et al. 2019; Esterhuyse and Scholtz 2015; Islam et al. 2015 
A Critical Study of Effectiveness of Online Learning on Students' Achievementanalyzed that A high score in achievement among students' taught and studied through online tools and online learning environment was found through this research. Similarly achievement among students of F2F teaching was found low, this is because in F2F learning, collaborating and sharing of resources is limited to the walls of classroom, but online learning made possible to learning, collaborating, and sharing of resources beyond four walls. Online learning environment provides features such as, user center, user control and communication, and making teaching learning process learner centric. (BAIG, 2011)

"Education in and After Covid-19: Immediate Responses and Long-Term Visions" focused to the following activities like the need to continue development of open educational platforms which allow access to the high quality of learning resources, The need to conduct quantitative and qualitative research and evaluate current models of online teaching and learning, with a particular focus to their long-term sustainability, The need to develop staff-teachers' capacity for online teaching, and professional staff capacity for supporting teachers and online systems. And on the need to encourage cooperation between universities, international organizations, private sector, civil society, and other stakeholders, to promote highquality online learning throughout the society (Zhu, 2020)

On the other hand the report "A Blueprint for Back to School "point outs Adapting to the challenges of COVID-19 gives schools the opportunity to provide what is uniquely possible in the schoolhouse while seeking new ways to fully use technology and community partnerships. We understand the enormity of these burdens. This is a moment when all of us-educators, families, and communities- must find ways to ensure that children get back the schools and connections so important to their young lives. When schools get the green light to go, they must be ready.

A recent survey done by the University of Hyderabad in the wake of the COVID-19 crisis shows that only $50 \%$ students had access to laptops and about $45 \%$ could, at best, access internet infrequently and further about $18 \%$ did not have internet access at all (UoH Herald 2020). This is the state of reality in a central university. Indeed, the speed of the internet and its fluctuations has seen major problems in many metro cities, let alone rural or small-town India, where many of our students are under the lockdown. In a lockdown condition, stuck within home, there are many corners of one's living space where data signal is weak. Further, many students do not have unlimited Wi-Fi plans, and have limited size data packs. Several classes in a day can be a substantial cost for many students in the low-income bracket. We know of several instances where students go out of their home in open street corners to access the internet or free Wi-Fi in normal times; even such ironical possibilities are, of course, closed during a lockdown. Thus, however keen they may be, many students are simply not enabled with the infrastructure to take part in an online teaching and learning process.

Imagining what education can be post-COVID-19: Indian novelist/activist Arundhati Roy (2020) has described the current COVID-19 pandemic as a portal. It is a pathway that leads to a reconfigured future, one that must be different from the world we previously knew. The pandemic's disproportionate, tragic consequences for health and livelihoods-for individuals, their communities, and even whole societies-underscore institutionalized forms of discrimination rooted in race, ethnicity, class, gender, sexual orientation, age, and abilities. These inequities are patently manifest in education systems around the world. The 
individuals most marginalized and discriminated against have suffered the greatest from the closure of schools and the efforts to reach students with online instruction. Delivery of education this way illustrates the difficulties posed for students who lack computers or who live in remote areas without electricity or Wi-Fi. These students might not even have space at home where they can work uninterrupted. Furthermore, fundamental services provided by schools have been significantly reduced or unavailable. We cannot go back to this unsatisfactory status quo. COVID-19's lessons compel us to imagine education systems in which students of all ages can thrive. We know that in many communities, schools are basic resource centers, often providing students with their only nutritious meal of the day. More than that, where equipped with a range of basic amenities, schools provide running water for showers and laundering. In metropolitan centers as well as in betterendowed rural communities, nurses and other health personnel may be available to attend to basic medical needs. Traumatized students and their parents may have access to counselors and social workers (Ewing and Johnson 2020).

"Education, the science of learning, and the COVID-19 crisis": The second part, of this study is taking the longer view, considers the potential negative impact of the COVID-19 crisis in increasing inequality in education; but also the potential positive impact of driving innovations in technology use for educating children. Children from homes with fewer resources and less opportunity for parental support risk falling behind, widening pre-existing gaps. Worse still, some children may feel unsafe in their homes. Children of well-of parents often live in bigger houses, have their own bedrooms, support from two parents rather than one, and better access to technology, books, and other learning resources, not to mention basics such as food. At least in school, pupils share the same spaces, lessons, teachers, and resources, which levels opportunities to some extent. Moreover, studying at home will affect some age groups more than others. Teenagers, whose emotional development propels them to move away from parents and careers and towards friends and peers, are likely to be more adversely affected.

This crisis has made it apparent that schoolprovided IT systems for computer based learning are becoming redundant. They are too expensive, too cumbersome, and too quickly out of date. Perhaps we need instead to move to personal devices integrated into schools. Just as we turn on Airplane Mode when we get on a plane, perhaps we will turn on Education Mode when we enter school. This suggests the policy solutions needed to reshape education through technology are not prescriptive, but regulatory. Policy needs to incentivize commercial developers to move into education. The role of policymakers, by contrast, should be to understand and mitigate the possible risks of technology use in children, as documented by research. As a starting point, these risks include screen time addiction and intolerance of boredom, displacement other activities (e.g., homework, play), social media bullying, unreliable information, sleep disruption, violent or otherwise age-inappropriate content, and data protection issues(Michael S. C. Thomas, 2020)

In the article "COVID-19 as a catalyst for educational change" they highlight some of the questions that schools can ask as they re imagine post-COVID-19 education. I am hopeful that COVID-19, because of its disruptions to education, can inspire more schools to think of online education not as a lesser version of face-to-face education, but as a different way to organize education. I am also hopeful that this disruption can inspire school leaders to reimagine education in terms of today's context and tomorrow's needs. 
Most important, I am hopeful that we can rethink education from the perspectives of the children instead of the curriculum. (Zhao, 2020)

In the study "COVID-19 causes unprecedented educational disruption: Is there a road towards a new normal?" concludes that Education could have benefited from better and more digital education solutions during the coronavirus crisis; thus, it is time to reflect on the role digital technology should have in the future of education. Governments and educational authorities have been deploying distance learning solutions: delivering content, supporting teachers, providing guidance to families, and addressing connectivity challenges in order to facilitate online instruction and distribution of learning material. But a danger looms: a new type of digital divide is bound to arise as students need laptops, tablets, or phones, as well as some type of internet access, in order to benefit from access to online material. The pandemic offers an opportunity for investments in education at all levels, to transform education and "leave no one behind", as envisaged in the SDGs. The Coalition will endeavor to match needs with free and secure solutions, to provide digital tools and learning management solutions, to upload national digitized educational resources, to curate resources for distance learning, and to strengthen technical expertise. Support to systemic education reform, in particular through effective guidelines and careful plans for reopening, will be equally crucial to ensure that when children do return to school; schools can adapt their classrooms and methods to provide the necessary safe environments for learners

The closure of schools, colleges, and universities does not only interrupt teaching: it also coincides with a key assessment period, and baccalaureate tests and exams have been postponed or cancelled in many countries. The careers of this year's university graduates may likewise be severely affected by the COVID-19 pandemic. They have experienced major interruptions in the final part of their studies, they are experiencing major interruptions in their assessments, and finally they are likely to graduate at the beginning of a major global recession. (d'Orville, 2020)

\section{Data Analysis}

TABLE 3.1

The table 3.1 analyses the gender of the respondents

\begin{tabular}{|l|l|l|}
\hline GENDER & $\begin{array}{l}\text { NUMBER OF } \\
\text { RESPONDENTS }\end{array}$ & PERCENT \\
\hline FEMALE & 620 & $51.67 \%$ \\
\hline MALE & 580 & $48.33 \%$ \\
\hline TOTAL & 1200 & $100 \%$ \\
\hline
\end{tabular}

for attending the online classes.

\section{GENDER OF THE RESPONDENTS}

Source: Primary Data

The table 3.1 shows the gender of the respondents. Majority of the them are female, out of 1200 respondents 620 are female, which constitute $51.67 \%$ and the remaining 580 respondents are male, they account $48.33 \%$ of the total respondents.

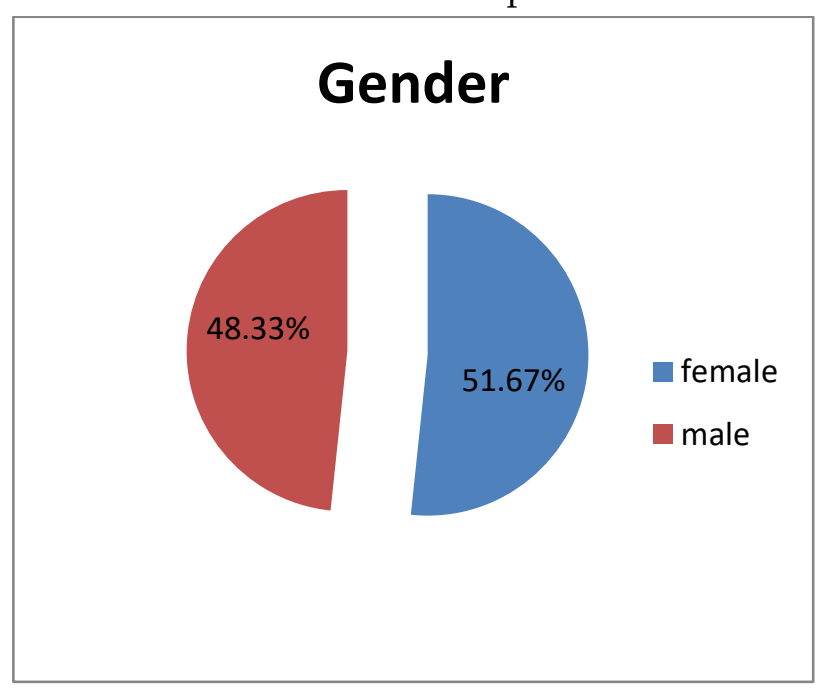


Cyndrella V S et al Int J Sci Res Sci \& Technol. November-December-2021, 8 (6) : 76-91

FIGURE 3.1

TABLE 3.2 
Table 3.2 depicts the age of the respondents for attending the online classes.

\section{AGE OF THE RESPONDENTS}

\begin{tabular}{|l|l|l|}
\hline $\begin{array}{l}\text { AGE } \\
\text { GROUP }\end{array}$ & $\begin{array}{l}\text { NO. OF } \\
\text { RESPONDENTS }\end{array}$ & PERCENT \\
\hline $15-17$ & 110 & $9.17 \%$ \\
\hline $18-20$ & 600 & $50 \%$ \\
\hline $21-25$ & 490 & $40.83 \%$ \\
\hline
\end{tabular}

Source: Primary Data

Table 3.2 depicts the age of the respondents. Majority of the respondents are aged between 18-20, they constitute $50 \%$ of the total respondents. It is clear $\mathrm{d}$ that undergraduate students afford online learning more when compared with other age groups. 490 of them belong to the age group 21-25, it means $40.83 \%$ of the total respondents and only 110 respondents are from the age group 15-17.

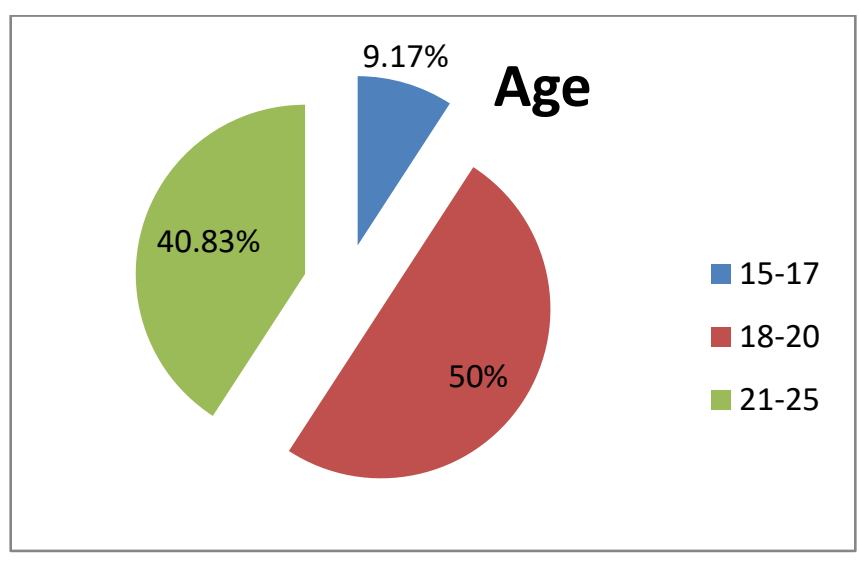

FIGURE 3.2

TABLE 3.3

The table 3.3 shows the most preferred platform by the respondents for their online learning.
MOST PREFERRED PLATFORM FOR ONLINE

\section{CLASSES}

\begin{tabular}{|l|l|l|}
\hline PLATFORM & $\begin{array}{l}\text { NO.OF } \\
\text { RESPONDENTS }\end{array}$ & PERCENT \\
\hline YOUTUBE & 226 & $18.83 \%$ \\
\hline $\begin{array}{l}\text { GOOGLE } \\
\text { MEET }\end{array}$ & 476 & $39.66 \%$ \\
\hline $\begin{array}{l}\text { GOOGLE } \\
\text { CLASSROOM }\end{array}$ & 458 & $38.16 \%$ \\
\hline ZOOM & 222 & $18.5 \%$ \\
\hline webexmeet & 83 & $6.91 \%$ \\
\hline OTHERS & 14 & $1.16 \%$ \\
\hline
\end{tabular}

Source: Primary Data

The table 3.3 shows the most preferred platform by the respondents for their online learning. Most of the them prefer Google meet, around $39.66 \%$ of the total. And Google classroom is second most preferred platform, which was chosen by $38.16 \%$ of the respondents. And $18.83 \%$ of the respondents prefer video lectures through YouTube and 18.5\% choose Zoom, $1.16 \%$ choose WebEx meet. Remaining $6.97 \%$ choose others like whatsapp, skype, telegram etc. 


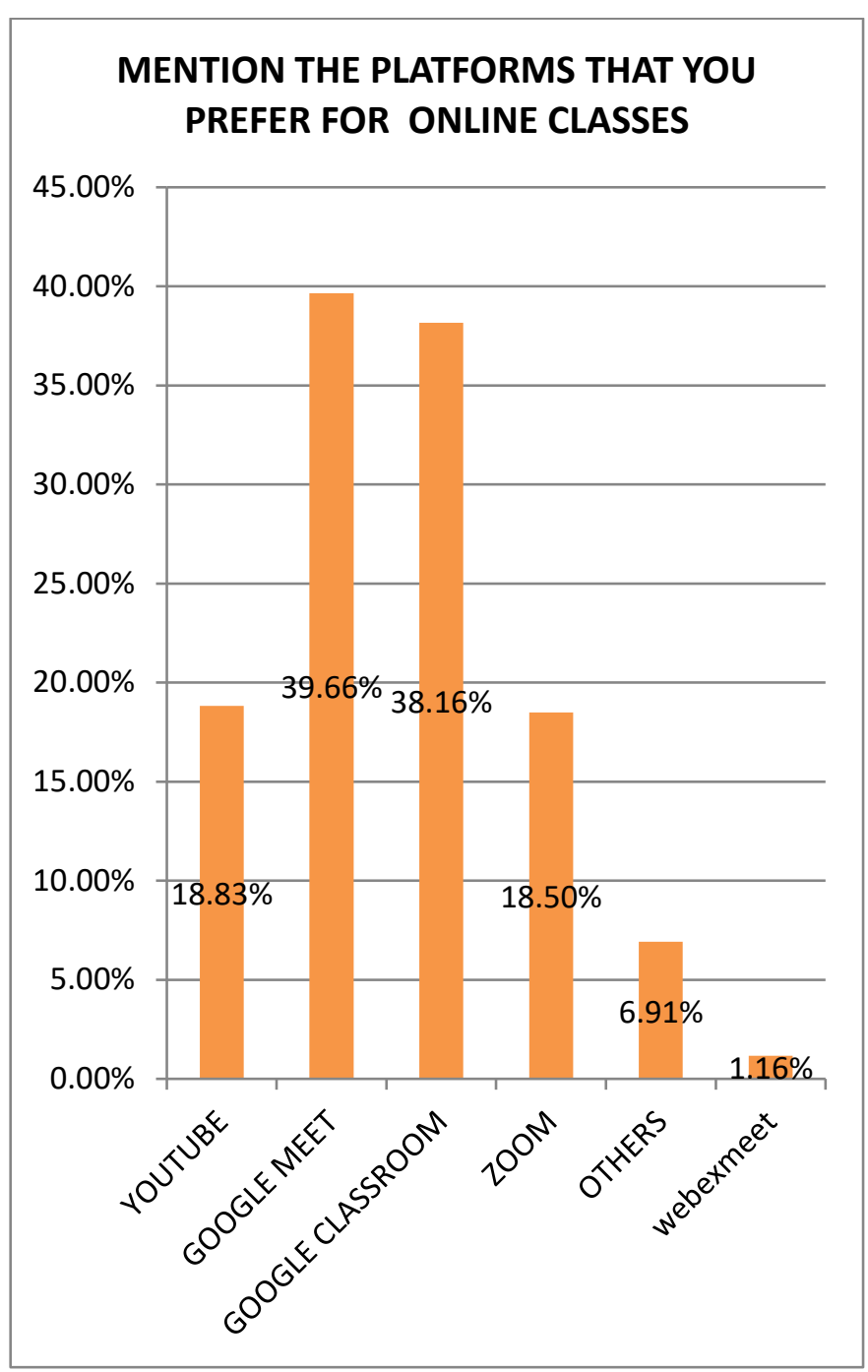

FIGURE 3.3

TABLE 3.4

\begin{tabular}{|l|l|l|}
\hline NG YOUR & & \\
OWN & & \\
PRESENTAT & & \\
IONS AND & & \\
CLASSES & & \\
\hline MAKING & 268 & $22.33 \%$ \\
ONLINE & & \\
TUTORIAL & & \\
VIDE & & $2.91 \%$ \\
\hline $\begin{array}{l}\text { ASSIGNING } \\
\text { VARIOUS }\end{array}$ & 35 & \\
MOOC & & \\
PROJECTS & & \\
\hline
\end{tabular}

Source: Primary Data

Table 3.4 deals with the most preferred mode of online teaching. It is clear $66.08 \%$ of the total respondents that is majority of the respondents prefer online classes using webex, zoom, google meet etc. And the second most preferred mode in online tutorial videos and conducting their on presentation is third in the list. And least preferred is assigning various MOOC projects. Thus it means that learners prefer class conducted by their teachers than any other alternative mode of learning.

Table 3.4 deals with the most preferred mode of online teaching.

PREFERRED ONLINE MODE OF TEACHING

\begin{tabular}{|l|l|l|}
\hline $\begin{array}{l}\text { ONLINE } \\
\text { MODE OF } \\
\text { TEACHING }\end{array}$ & $\begin{array}{l}\text { RO.OF } \\
\text { RESPONDENTS }\end{array}$ & \\
\hline $\begin{array}{l}\text { ONLINE } \\
\text { CLASSES } \\
\text { USING } \\
\text { WEBEX, } \\
\text { ZOOM, } \\
\text { GOOGLE } \\
\text { MEET ETC }\end{array}$ & 793 & $66.08 \%$ \\
\hline CONDUCTI & 104 & \\
\hline
\end{tabular}




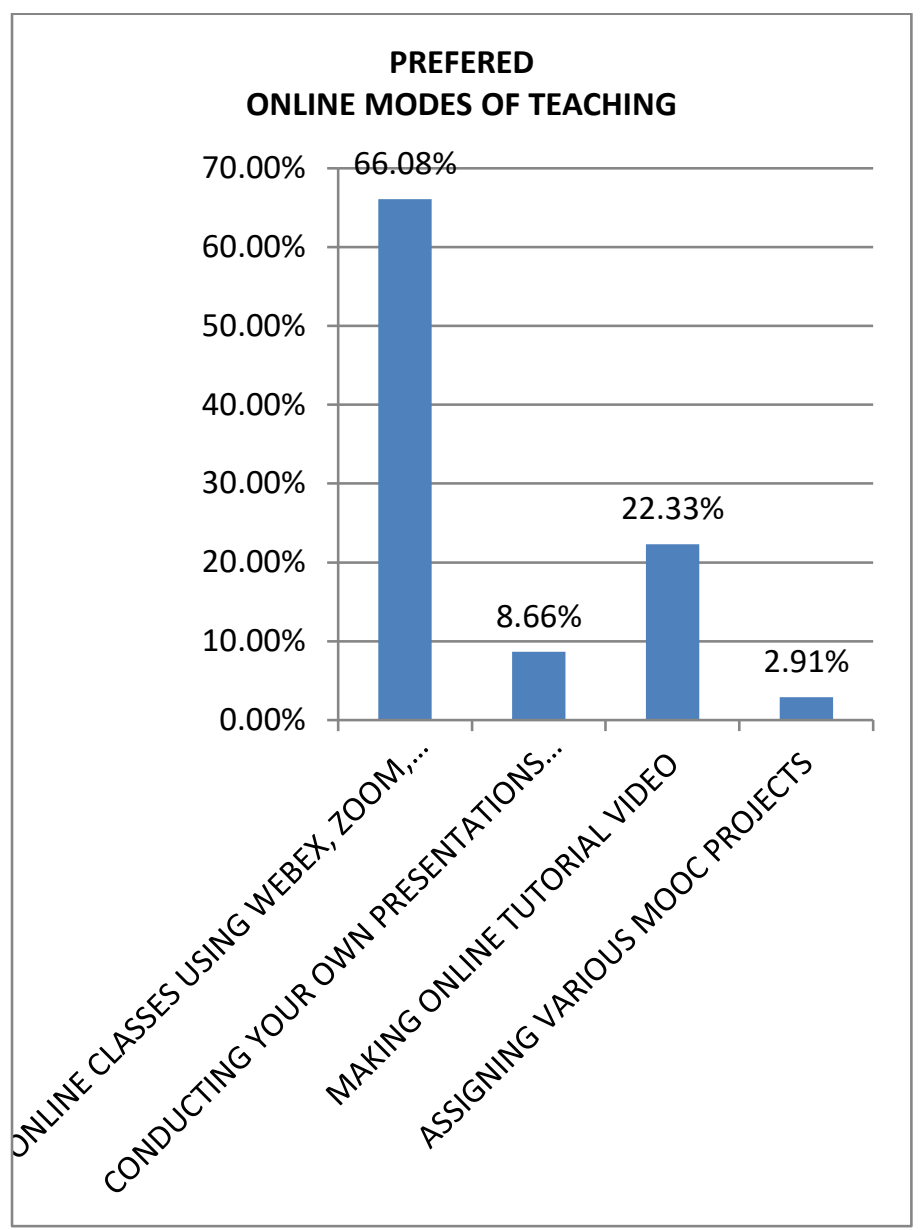

FIGURE 3.4

TABLE 3.5

The table 3.5 shows the data regarding how long the respondents have been using online platforms for their academic purpose.

HOW LONG RESPONDENTS HAVE BEEN USING ONLINE PLATFORM FOR THEIR STUDIES

\begin{tabular}{|l|l|l|}
\hline $\begin{array}{l}\text { TIME } \\
\text { PERIOD }\end{array}$ & $\begin{array}{l}\text { NO.OF } \\
\text { RESPONDENTS }\end{array}$ & PERCENT \\
\hline $\begin{array}{l}\text { LESS } \\
\text { THAN A } \\
\text { YEAR }\end{array}$ & 890 & $74.16 \%$ \\
\hline $1-5$ YEARS & 276 & $23 \%$ \\
\hline $\begin{array}{l}5-10 \\
\text { YEARS }\end{array}$ & 34 & $2.83 \%$ \\
\hline \begin{tabular}{l} 
TOTAL \\
\hline
\end{tabular} & 1200 & $100 \%$ \\
\hline
\end{tabular}

Source: Primary Data
The table 3.5 shows the data regarding how long the respondents have been using online platforms for their academic purpose. $74.16 \%$ of the respondents have been using online platforms since the last year, it means Covid-19-19 made a positive impact on online learning, as it forced forced the students to study online. Of the remaining respondents $23 \%$ have been using online platforms since last 5 years and only $2.83 \%$ have been using online platforms since last 10 years.

\section{HOW LONG HAVE YOU BEEN USING ONLINE PLATFORMS FOR ACADEMIC PURPOSES}

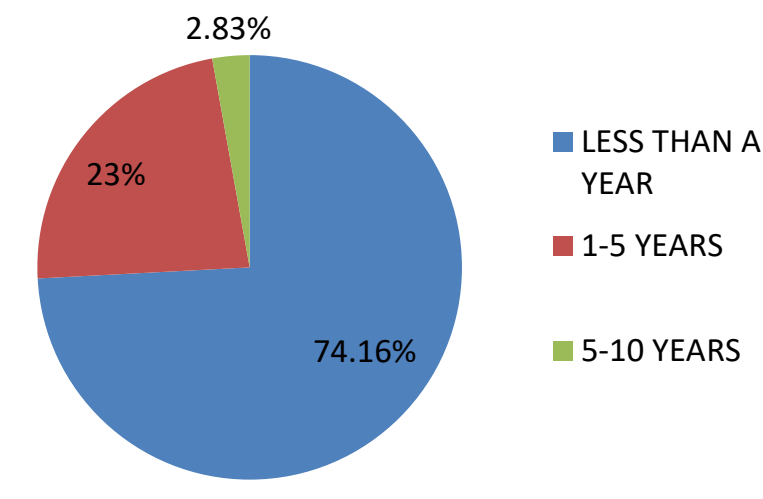

FIGURE 3.5

TABLE 3.6

The table 3.6 analyses the opinion of the respondents regarding the impact of Covid-19 on education system.

OPNION ON THE IMPACT OF COVID-19 IN EDUCATION SYSTEM

\begin{tabular}{|l|l|}
\hline OPINION & NO.OF RESPONDENTS \\
\hline YES & 1028 \\
\hline NO & 172 \\
\hline TOTAL & 1200 \\
\hline
\end{tabular}

Source: Primary Data 
The table 3.6 analyses the opinion of the respondents regarding the impact of Covid-19 on education system. The pandemic Covid-19 was mainly affected the health system of a country. But in order to prevent the community spread, many countries were forced to lockdown the entire activities. And hence the educational institutions were forced to close, exams were postponed. From the data it is clear that majority of the respondents that is $85.66 \%$ argued that Covid- 19 has affected the education system and especially in method of teaching, learning and the assessment of students etc.
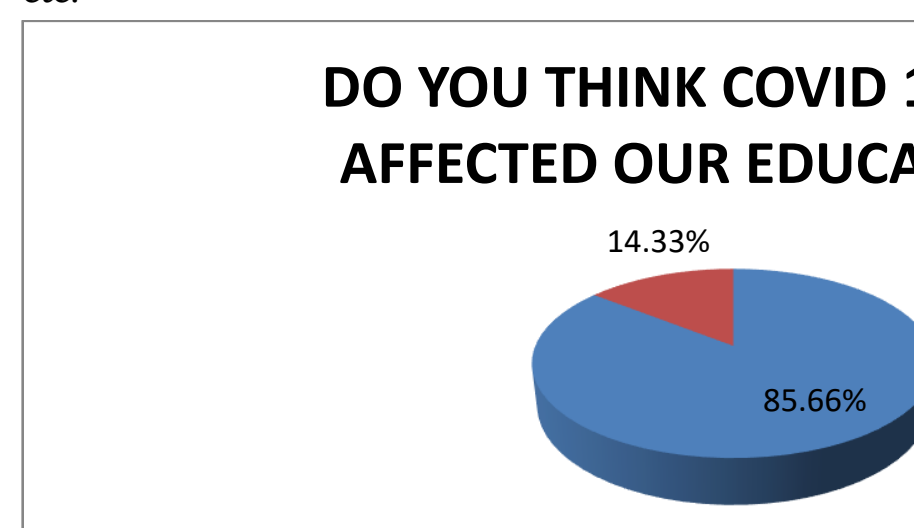

FIGURE 3.6

TABLE 3.7

Table 3.7 studies the impact of Covid-19 on education.

IMPACT OF COVID-19 ON STUDIES

\begin{tabular}{|l|l|l|}
\hline OPINION & $\begin{array}{l}\text { NO.OF } \\
\text { RESPONDENTS }\end{array}$ & PERCENT \\
\hline $\begin{array}{l}\text { A BIT } \\
\text { BETTER }\end{array}$ & $22.83 \%$ & 274 \\
\hline $\begin{array}{l}\text { THE } \\
\text { SAME }\end{array}$ & $18.33 \%$ & 220 \\
\hline $\begin{array}{l}\text { A BIT } \\
\text { WORSE }\end{array}$ & $58.83 \%$ & 706 \\
\hline TOTAL & 1200 & $100 \%$ \\
\hline
\end{tabular}

Source: Primary Data

Table 3.7 studies the impact of Covid-19 on education. $58.83 \%$ of the respondents argue that
Covid-19 has a negative impact on their studies. It means most of the respondents prefer classroom teaching than online alternatives. On the other hand $22.83 \%$ argued that Covid-19 has a positive impact on their studies. So they prefer online teaching than conventional mode of teaching. The remaining $18.33 \%$ of the respondents argue that the Covid-19 does not affect their studies.

\section{HOW LONG DO YOU THINK r AFFECTED YOUR STUDIES IN YEARS FROM NOW COMPARED}

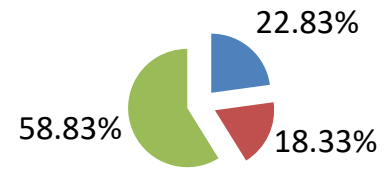

FIGURE 3.7

TABLE 3.8

Table 3.8 reveals the opinion of respondents regarding this paradigm shift in having online education.

OPINION ON PARADIGM SHIFT IN EDUCATION

\begin{tabular}{|l|l|l|}
\hline OPINION & $\begin{array}{l}\text { NO.OF } \\
\text { RESPONDENTS }\end{array}$ & PERCENT \\
\hline yes & 675 & $56.25 \%$ \\
\hline no & 525 & $43.75 \%$ \\
\hline TOTAL & 1200 & $100 \%$ \\
\hline \multicolumn{2}{|c|}{ Source: Primary Data }
\end{tabular}

Table 3.8 reveals the opinion of respondents regarding this paradigm shift. From the table it is found that $56.25 \%$ of them, that is majority of the respondents support online education and they are willing to accept the recent changes in education. But the remaining $43.75 \%$ of the respondents are not accepting this paradigm shift, it might be due to many reasons like lack of connectivity, lack of ICT 
devices, not able to study through online, lack of technical knowledge etc...

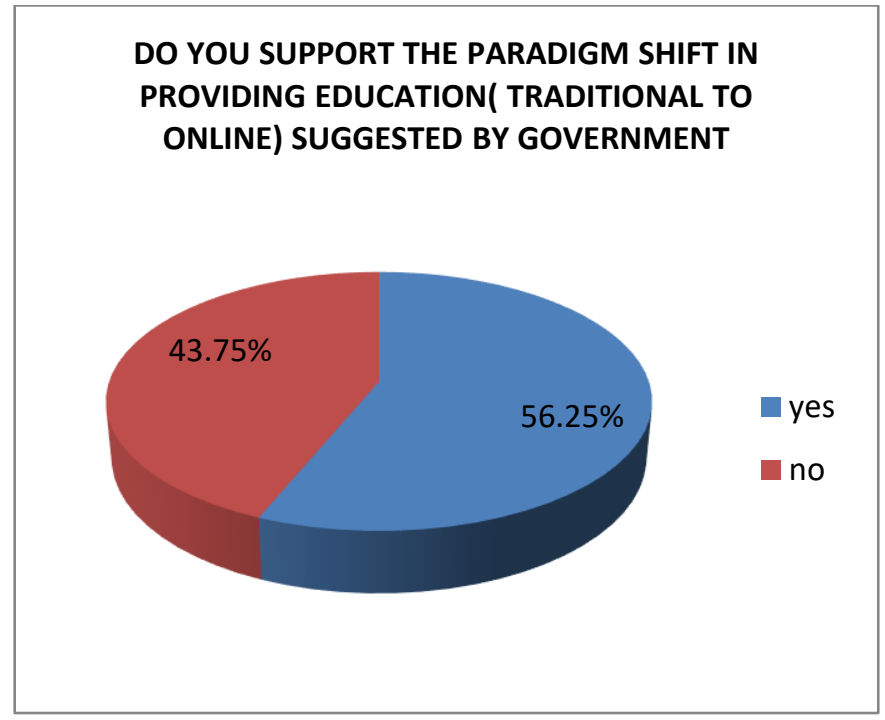

FIGURE 3.8

\section{TABLE 3.9}

The table 3.9 investigates the challenges faced by the respondents while accessing online classes.

\section{CHALLENGES FACED IN ONLINE LEARNING}

\begin{tabular}{|l|l|l|}
\hline CAHALLENGES & $\begin{array}{l}\text { NO.OF } \\
\text { RESPONDEN } \\
\text { TS }\end{array}$ & $\begin{array}{l}\text { PERCEN } \\
\mathrm{T}\end{array}$ \\
\hline $\begin{array}{l}\text { DIFFICULTY IN } \\
\text { CONNECTIVITY }\end{array}$ & 605 & $50.41 \%$ \\
\hline $\begin{array}{l}\text { DIFFICULTY IN } \\
\text { ACCESIBILITY } \\
\text { OF LAPTOP, } \\
\text { MOBILES }\end{array}$ & 272 & $22.66 \%$ \\
\hline $\begin{array}{l}\text { DIFFICULTY IN } \\
\text { UNDERSTANDIN } \\
\text { G ONLINE } \\
\text { CLASSES OF }\end{array}$ & 303 & $25.25 \%$ \\
\hline $\begin{array}{l}\text { LACK OF } \\
\text { COMPUTER } \\
\text { LITERACY } \\
\text { FROM } \\
\text { PART } \\
\text { TEACHERS }\end{array}$ & 1200 & $100 \%$ \\
\hline TOTAL & & \\
\hline
\end{tabular}

Source: Primary Data
The table 3.9 investigates the challenges faced by the respondents while accessing online classes. Majority of them, that is $50.41 \%$ of the total respondents faces connectivity issues like network problems and $25.25 \%$ face the difficulty in studying and understanding online classes and $22.66 \%$ face the problem due to lack of ICT devices such as laptops, mobiles etc... and only $1.67 \%$ argue that they face difficulty due lack of computer literacy from the part of teachers.

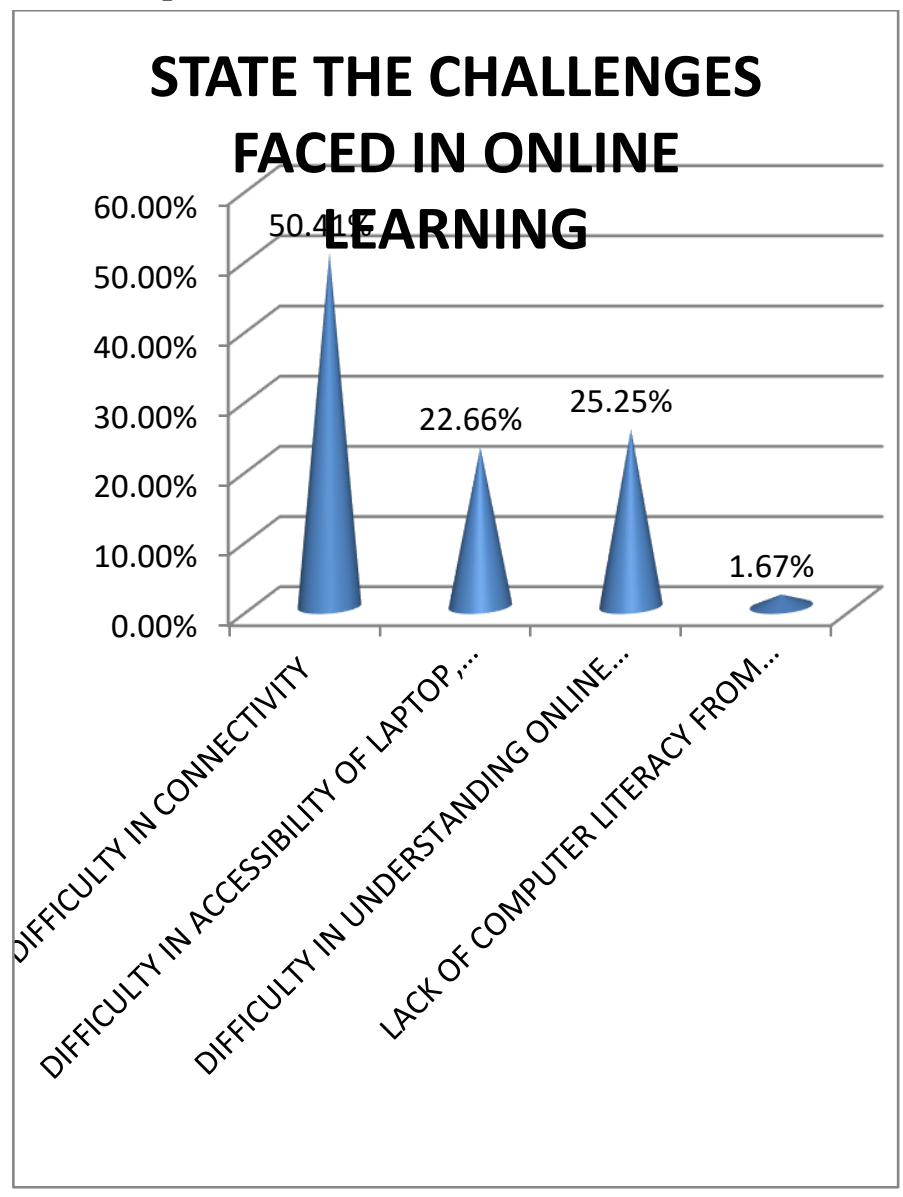

TABLE 3.10

LEVEL OF CONFIDENCE IN ATTENDING EXAMS AFTER STUDYING THROUGH ONLINE CLASS

\begin{tabular}{|l|l|l|}
\hline $\begin{array}{l}\text { CONFIDENCE } \\
\text { LEVEL }\end{array}$ & $\begin{array}{l}\text { NO.OF } \\
\text { RESPONDENTS }\end{array}$ & PERCENT \\
\hline $\begin{array}{l}\text { NOT } \\
\text { CONFIDENT } \\
\text { AT ALL }\end{array}$ & 148 & $12.33 \%$ \\
\hline SOMEWHAT & 269 & $22.41 \%$ \\
\hline
\end{tabular}


Cyndrella V S et al Int J Sci Res Sci \& Technol. November-December-2021, 8 (6) : 76-91

\begin{tabular}{|l|l|l|}
\hline CONFIDENT & & \\
\hline NEUTRAL & 488 & $40.66 \%$ \\
\hline CONFIDENT & 194 & $16.16 \%$ \\
\hline $\begin{array}{l}\text { HIGHLY } \\
\text { CONFIDENT }\end{array}$ & 101 & $8.41 \%$ \\
\hline TOTAL & 1200 & $100 \%$ \\
\hline $\begin{array}{l}\text { MEAN } \\
\text { SCORE }\end{array}$ & 2.86 & \\
\hline
\end{tabular}

Source: Primary Data

From the table 3.10 and mean score 2.86, we can conclude that level of confidence in attending exam after studying through online classes is neutral. If the mean score is above 4 , we can conclude that majority respondents are confident and if it was less than 2 we can conclude that they are not confident. But mean score 2.86 implies that most of the respondents have neutral opinion regarding their confidence level.

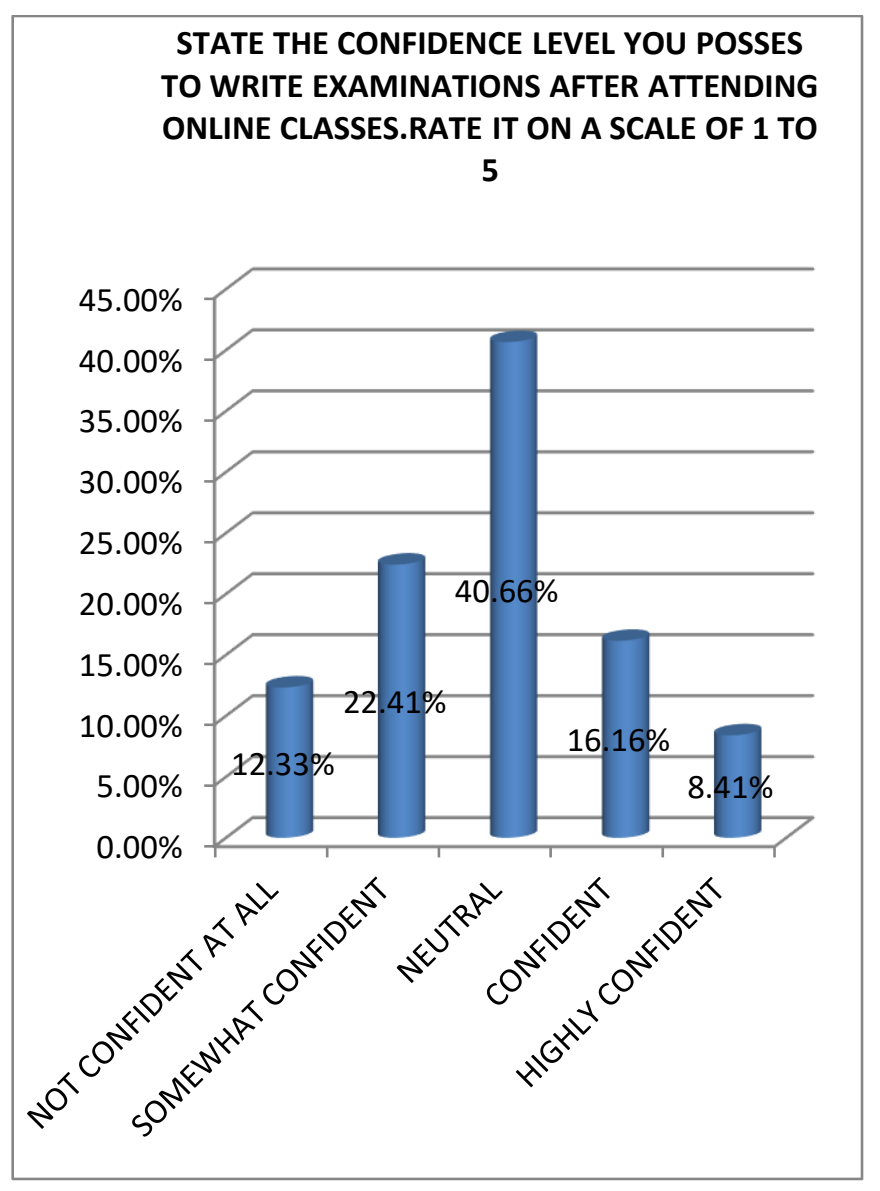

FIGURE 3.10

TABLE 3.11

The Table 3.11 investigates the degree of acceptance towards online platforms.

\section{LEVEL OF ACCEPTANCE TOWARDS ONLINE PLATFORMS}

\begin{tabular}{|l|l|l|}
\hline $\begin{array}{l}\text { ACCEPTANCE } \\
\text { LEVEL }\end{array}$ & $\begin{array}{l}\text { NO.OF } \\
\text { RESPONDENTS }\end{array}$ & PERCENT \\
\hline $\begin{array}{l}\text { NOT } \\
\text { ACCEPTABLE } \\
\text { AT ALL }\end{array}$ & 119 & $9.91 \%$ \\
\hline $\begin{array}{l}\text { NOT } \\
\text { ACCEPTABLE }\end{array}$ & 233 & $19.41 \%$ \\
\hline NEUTRAL & 479 & $39.91 \%$ \\
\hline ACCEPTABLE & 264 & $22 \%$ \\
\hline $\begin{array}{l}\text { HIGHLY } \\
\text { ACCEPTABLE }\end{array}$ & 105 & $8.75 \%$ \\
\hline TOTAL & 1200 & $100 \%$ \\
\hline MEAN SCORE & 3.00 & \\
\hline
\end{tabular}

\section{Source: Primary Data}

Table 3.11 investigates the degree of acceptance towards online platforms. The mean score 3.00, implies that it is neither "acceptable" nor "not acceptable" to the majority of respondents. Here, most of respondents have neutral opinion regarding the acceptability of online classes.

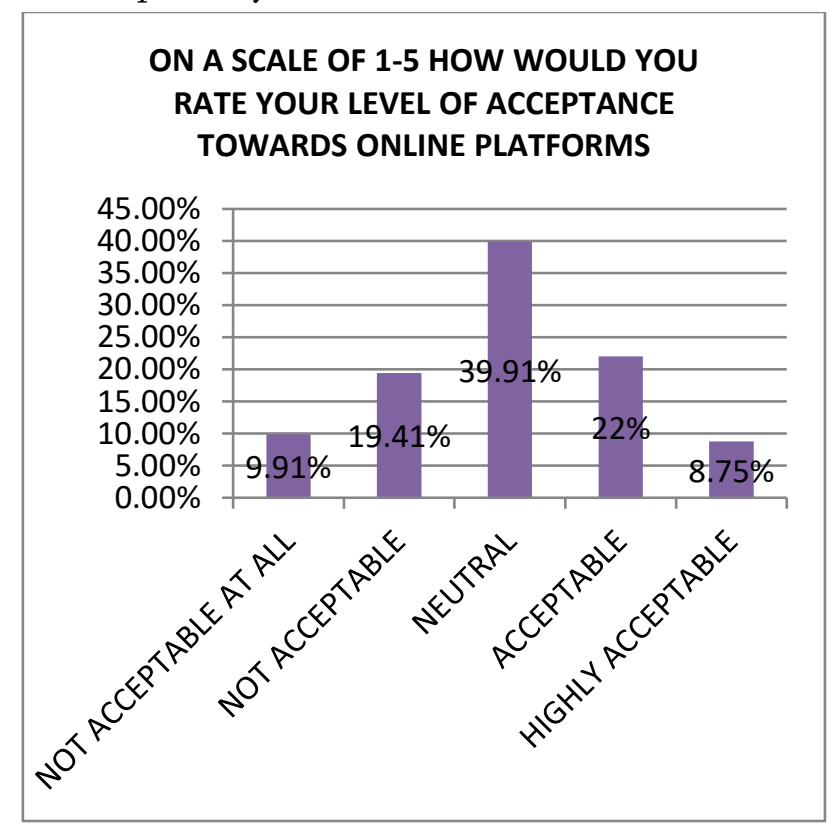

FIGURE 3.11 


\section{FINDINGS}

- Most preferred online platform by respondents are Google meet and Google classroom

- The respondents prefer live online classes than other alternatives

- Spread of Covid-19 compelled students to adopt online learning

- $\quad$ Like other sectors in the economy, education sector was also highly affected due to the spread of Covid-19.

- Most of the respondents are in a opinion that online platform cannot substitute conventional classroom

- $\quad$ Majority of respondents agree that , they will support the paradigm shift in education

- $\quad$ The greatest challenge faced by students is connectivity issues

- The respondents have neutral opinion on level of confidence in attending exam after studying through online platforms

- Most of the respondents have neutral opinion on the level on acceptance of online classes

- Apart from connectivity issues, respondents face challenge due to lack of ICT devices to access online classes

\section{SUGGESTIONS}

Since majority of our respondents say that their education was highly affected in the sense of assessments, careers, higher studies, etc, Government should create new employment platforms by the way of work from home opportunities, new options, for higher studies like sanctioning of new courses and likewise.

Generate education projects like providing printed education materials to be made available in offline mode to those students cannot access it. Ensuring that each village gets at least one good network connectivity in remote areas, where there is disruption in availing internet facility.

Strict rules as to provide e content for all subjects which is being taught in all university, by making an e repository.

Adopt a national strategy for digital education by focusing the principal of equitable distribution for all. It includes providing good connectivity, infrastructure, proven software for all students irrespective of economic status.

Since the students face lack of confidence to face examinations, online assessments should also be blended with online education.

\section{VII.CONCLUSION}

NEP has paved a pathway for excellence in education and employment simultaneously. Also work from home opportunities, new options, for higher studies like sanctioning of new courses are also coming up, it should be implemented soon. Government should Generate offline education projects, E- Repository digitalization of villages. With all this there would be equitable distribution of education for all students.

\section{REFERENCES}

[1]. https://link.springer.com/article/10.1007/s111 25-020-09464-3\#citeas

[2]. https://link.springer.com/content/pdf/10.1007 /s11125-020-09474-1.pdf

[3]. http://www.jstor.com/stable/resrep24606

[4]. https://iproxy.inflibnet.ac.in:2113/author/epw -engage

[5]. Economic and political weekly

[6]. https://link.springer.com/article/10.1007/s111 25-020-09468-z 
[7]. https://link.springer.com/content/pdf/10.1007 /s11125-020-09477-y.pdf

[8]. https://link.springer.com/content/pdf/10.1007 /s11125-020-09475-0.pdf

\section{Cite this article as :}

Cyndrella V S , "Effectiveness of Technology Based Online Teaching Pedagogy During Covid-19", International Journal of Scientific Research in Science and Technology (IJSRST), Online ISSN : 2395-602X, Print ISSN : 2395-6011, Volume 8 Issue 6, pp. 76-91, November-December 2021. Available at doi : https://doi.org/10.32628/IJSRST218523

Journal URL : https://ijsrst.com/IJSRST218523 